\title{
Identification of $\mathrm{ABCG}^{+}$cells in nasopharyngeal carcinoma cells
}

\author{
HONGBO ZHANG ${ }^{1 *}$, WEIDONG LIU ${ }^{1 *}$, XIANGLING FENG ${ }^{1}$, LEI WANG $^{1}$, \\ XINGJUN JIANG ${ }^{2}$, DINGYANG LIU ${ }^{2}$, LIHUA ZHANG ${ }^{1}$, BIN ZHU ${ }^{1}$, \\ WEN ZHOU ${ }^{1}$, WENTING JIA ${ }^{1}$, GUIFEI LI ${ }^{1}$ and CAIPING REN ${ }^{1}$

\begin{abstract}
${ }^{1}$ Cancer Research Institute, Xiang-Ya School of Medicine, Central South University, Key Laboratory for Carcinogenesis of Chinese Ministry of Health, Key Laboratory for Carcinogenesis and Cancer Invasion of Chinese Ministry of Education, Hunan 410078; ${ }^{2}$ Department of Neurosurgery, Xiangya Hospital, Central South University, Hunan 410008, P.R. China
\end{abstract}

Received November 9, 2011; Accepted December 12, 2011

DOI: 10.3892/or.2011.1618

\begin{abstract}
Tumor stem cells are a small subset of tumor cells with the ability of self-renewal and differentiation and are regarded as a cause of tumor growth and recurrence. Previously we have shown that stem-like label-retaining cells (LRCs) can be detected in nasopharynx, tongue, esophagus and xenograft tumors formed by nasopharyngeal carcinoma (NPC) cell lines (5-8F, 6-10B and TMNE). The present study aimed to identify $\mathrm{ABCG}^{+}$cells in 5-8F NPC cells and compare their tumorigenic potential with $\mathrm{ABCG} 2^{-}$cells, expecting that we can obtain insight into the mechanism of the differential phenotypes of $\mathrm{ABCG}^{+}$and $\mathrm{ABCG} 2^{-}$cells. By using magnetic cell sorting (MACS) method, we isolated $\mathrm{ABCG}^{+}$cells and $\mathrm{ABCG} 2^{-}$cells from 5-8F cells. Among these two subpopulations and unsorted $5-8 \mathrm{~F}$ cells, the rate of $\mathrm{ABCG} 2^{+}$cells at $\mathrm{G} 1$ phase was highest, while the rate of $\mathrm{ABCG} 2^{-}$cells at $\mathrm{S}$ phase was highest, indicating that $\mathrm{ABCG}_{2}{ }^{+}$cells were mostly quiescent. However, $\mathrm{ABCG}^{+}$ cells showed lower cloning efficiency and tumorigenicity than ABCG2- cells. We also used Affymetrix U133 plus 2.0 human whole genome expression chip to identify the gene expression profile of $\mathrm{ABCG}^{+}$and $\mathrm{ABCG} 2^{-}$cells and found that both subpopulations expressed some stem cell associated genes, e.g., PSCA, ABCG2 and ALPI were expressed in ABCG2 ${ }^{+}$cells, and $\mathrm{K} 19$, integrin $\alpha 6$, integrin $\beta 4$, CD44 and K14 were expressed in ABCG2- cells, suggesting there were stem cells in both $\mathrm{ABCG}^{+}$ and $\mathrm{ABCG}^{-}$cells. Our data demonstrated that there exist $\mathrm{ABCG}^{+}$cells in NPC cells, but ABCG2 alone is not sufficient for isolating cancer stem cells in 5-8F NPC cells.
\end{abstract}

Correspondence to: Professor Caiping Ren, Cancer Research Institute, Xiang-Ya School of Medicine, Central South University, Key Laboratory for Carcinogenesis of Chinese Ministry of Health, Key Laboratory for Carcinogenesis and Cancer Invasion of Chinese Ministry of Education, Changsha, Hunan 410078, P.R. China E-mail: rencaiping@csu.edu.cn

${ }^{*}$ Contributed equally

Key words: ABCG2, cancer stem cell, nasopharyngeal carcinoma

\section{Introduction}

Stem cells, with the ability to proliferate infinitely through self-renewal and differentiation, can be isolated and cultured from inner cell mass of blastocyst (1), primordial germ cells (2), bone marrow (3), brain (4), skin (5), digestive canal (6), respiratory tract (7), cornea (8), muscle (9), liver (10), pancreas (11) and lung (12). Many tumors contain a sub-population of stem cells known as cancer stem cells (CSCs). CSC has unlimited potential for self-renewal and can drive tumorigenesis and develop multidrug resistance $(13,14)$. To date, CSCs have been identified in human leukemia (15) and in solid tumors including breast (16), bladder (17), colorectal (18), gastric (19), hepatocellular (20) and lung carcinomas (21), malignant melanoma (22), nasopharyngeal (23), pancreatic (24), prostate (25) and renal carcinomas (26). However, the characterization of CSC remains insufficient and CSC has not been isolated from some tumors. CSC is regarded as the root of cancer, and thus should be more important for cancer therapy than other tumor cells. Therefore, CSC might be a good therapeutic target for cancer treatment.

Side population (SP) cells, originally isolated from murine hematopoietic stem cells using their characteristic to efflux Hoechst 33342 dye and FACS method (27), have been sorted from many normal human tissues such as heart (28), prostate (29), limbal epithelium (30), skin (31), mammary gland (32) and kidney (33), and have also isolated from human cancer cells such as small cell lung cancer (34), glioma (35), prostate cancer (36), leukemia (37), neuroblastoma (38), hepatoma (39), nasopharyngeal carcinoma (23), colorectal cancer (39), thyroid cancer (40) and lung cancer (41). Cancer SP cells exhibit stem cell-like functions such as resistance to chemotherapy drugs, clonogenic ability and tumorigenicity. Therefore, SP cells can be regarded as a kind of enriched CSCs.

The phenotype of SP cells depends on the expression of ABCG2, a member of ATP binding cassette (ABC) transporters which belong to one of the largest transmembrane protein families. They use ATP to transport various substrates across cell membranes. The substrates include chemotherapy drugs, metabolites and other compounds such as Hoechst 33342 dye. To present, about $50 \mathrm{ABC}$ transporters have been identified (42) and are divided into seven subfamilies (from 
A to $\mathrm{G}$ ), among which ABCG2 is the second member of the G subfamily. ABCG2 was first identified in doxorubicinresistant human MCF-7 breast cancer cells and thus also named as breast cancer resistance protein (BCRP) (43). It is widely distributed in normal tissues and stem cells including SP cells. High expression of ABCG2 has been detected in CSCs isolated from embryonic cancer (44), retinoblastoma (45), lung (41), liver (46), pancreas (47) and gallbladder cancer (48).

Previously we have identified LRCs in nasopoharyngeal epithelia and NPC xenograft tissues with bromodeoxyuridine (BrdU) (49). In this study, we isolated ABCG2 ${ }^{+}$and ABCG2 ${ }^{-}$cells from 5-8F NPC cells by using MACS and then characterized their biological properties and expression profiles. Our results suggest that ABCG2 alone is insufficient to identify CSCs in 5-8F NPC cells.

\section{Materials and methods}

Ethics statement. All animal work was performed under the institutional guidelines approved by the Animal Care and Use Committee of Central South University. The present study was also approved ethically by the institutional review board of Central South University.

Double labeling detection for LRC and ABCG2 expression in $5-8 F$ cells. We used immunofluorescence method to detect LRCs and ABCG2 expression in 5-8F cells. Briefly, 5-8F cells was labeled with BrdU, inoculated into nude mice and traced for 8 weeks. Then, the tissue sections were made from formed tumor blocks, hydrated, treated with $3 \% \mathrm{H}_{2} \mathrm{O}_{2}$ for $10 \mathrm{~min}$ to remove endogenous peroxidase, with $2 \mathrm{~N}$ hydrochloric acid for $30 \mathrm{~min}$ at $37^{\circ} \mathrm{C}$, with $0.1 \mathrm{M}$ sodium borate for $4 \mathrm{~min}$ and then treated with $0.25 \%$ trypsin and washed with PBS after each above treatment. The treated tissue sections was added with antibody for BrdU (Sigma, St. Louis, MO) at $4^{\circ} \mathrm{C}$ overnight. After washing with PBS, the sections was added with goat anti-mouse IgG-FITC antibody (Santa Cruz Biotechnology, Santa Cruz, CA) and incubated for $30 \mathrm{~min}$ at RT. After washing with PBS, the sections were blocked with normal goat serum, added with mouse anti-human ABCG2 antibody (BD Pharmingen, USA), for $30 \mathrm{~min}$ at RT, then added with Texas Red conjugated goat anti-mouse IgG (Santa Cruz Biotechology) and incubated for $30 \mathrm{~min}$ at RT. After washing with PBS, the sections were observed and photographed with a fluorescence microscope.

Separation of $A B C G 2^{+}$cells by MACS. 5-8F NPC cells were harvested, prepared into single cell suspension and counted. Less than $10^{8}$ cells were obtained for cell sorting. The volume of cell suspension was adjusted to $200 \mu \mathrm{l}$ with $1 \mathrm{X}$ PBS containing $0.5 \%$ bovine serum albumin (BSA). Mouse antihuman ABCG2 antibody ( $20 \mu \mathrm{l})$ was added to the cell solution, mixed and incubated for $20 \mathrm{~min}$ at $4-8^{\circ} \mathrm{C}$. The cells were washed with $1 \mathrm{X}$ PBS containing $0.5 \%$ BSA three times and the cell volume was adjusted to $200 \mu \mathrm{l}$. The goat anti-mouse IgG2a bound with magnetic beads (Miltenyi Biotec, Germany) was added to the cell solution, mixed and incubated for $20 \mathrm{~min}$ at $4-8^{\circ} \mathrm{C}$ and then washed with $1 \mathrm{X}$ PBS containing $0.5 \% \mathrm{BSA}$. The cells were harvested and the volume of cell suspension was adjusted to $0.5 \mathrm{ml}$. The sorting column was fixed on magnetic sorting stand (Miltenyi Biotec) and equilibrated by applying $0.5 \mathrm{ml} 1 \mathrm{X}$ PBS containing $0.5 \% \mathrm{BSA}$. The bound cell suspension $(0.5 \mathrm{ml})$ was applied to the column and the effluent was harvested. $1 \mathrm{X}$ PBS $(0.5 \mathrm{ml})$ containing $0.5 \%$ BSA was applied to the column two times. The effluent was ABCG2 ${ }^{-}$cell fraction. Another $1 \mathrm{ml}$ of $1 \mathrm{X}$ PBS containing $0.5 \%$ BSA was applied to the column, the effluent was repeated for application to new columns and the $\mathrm{ABCG} 2^{+}$cells were subsequently enriched. The final effluent was centrifuged for $5 \mathrm{~min}$ at $4^{\circ} \mathrm{C}$, $1,000 \mathrm{rpm}$ to obtain the cells.

Identification of sorting effect. We used immunocytochemistry method to identify the purity of $\mathrm{ABCG} 2^{+}$cells. Briefly, enriched $\mathrm{ABCG} 2^{+}$were made into cell pellets. The cell pellets were treated with $3 \% \mathrm{H}_{2} \mathrm{O}_{2}$ for $10 \mathrm{~min}$, with $0.25 \%$ trypsin for $15 \mathrm{~min}$ and blocked with normal goat serum for $20 \mathrm{~min}$. The cells were added with mouse anti-human ABCG2 antibody and incubated at $4^{\circ} \mathrm{C}$ overnight. After washing with PBS, the cells were added with goat anti-mouse IgG-HRP and incubated for $30 \mathrm{~min}$ at RT. After washing with PBS, the cells were developed with AEC (Zhongshan Goldenbridge Biotech Co., Ltd., China), counterstained with hematoxylin and mounted with Glycerol vinyl alcohol aqueous mounting solution (GVA, Zymed Laboratories, Inc., USA). The red $\mathrm{ABCG}^{+}$cells were observed with an optical microscope and the purity was calculated.

We also used flow cytometry to identify the purity of $\mathrm{ABCG}^{+}$cells. The MACS-sorted $\mathrm{ABCG} 2^{+}$cells were resuspended, added with anti-human ABCG2 antibody-FITC (1:200), incubated for $30 \mathrm{~min}$ at $4-8^{\circ} \mathrm{C}$ and washed with $1 \mathrm{ml}$ of $1 \mathrm{X}$ PBS containing $0.5 \%$ BSA three times. Then the purity of $\mathrm{ABCG}^{+}$cells was measured with flow cytometry (FACS Calibur, BD, USA). Unsorted 5-8F cells added with IgG-FITC were used as control.

Cloning efficiency determination. Colony formation assay was performed as previously described (50). Briefly, single cell suspension was prepared from $\mathrm{ABCG} 2^{+}, \mathrm{ABCG} 2^{-}$and unsorted $5-8 \mathrm{~F}$ cells and counted. Each cell type was seeded in 12-well plates (200 cells/well) and cultured at $37^{\circ} \mathrm{C}$ for 14 days in an incubator with $5 \% \mathrm{CO}_{2}$. Then the cells were fixed with methanol and stained with $0.4 \%$ crystal violet. Colonies containing at least 50 cells were counted under an inverse microscope. Cloning efficiency $(\%)=$ cell colony amounts $/ 200 \times 100 \%$.

Cell cycle analysis. ABCG2+ ${ }^{+}$ABCG2- and unsorted 5-8F cells $\left(2 \times 10^{6}\right)$ were harvested, respectively, washed with PBS, fixed with $70 \%$ ice-cold ethanol for $30 \mathrm{~min}$. The ethanol was discarded and the cells were resuspended in $500 \mu \mathrm{l}$ PBS, added with RNase A to a final concentration of $100 \mu \mathrm{g} / \mathrm{ml}$, incubated at $37^{\circ} \mathrm{C}$ for $30 \mathrm{~min}$, stained with $20 \mu \mathrm{g} / \mathrm{ml}$ of propidium iodide (PI) for $30 \mathrm{~min}$, measured with flow cytometry and analyzed with Mod Fit LT software.

Analysis of tumorigenesis in NOD/SCID mice. ABCG2+, ABCG2- and unsorted 5-8F cells $\left(10^{2}, 10^{3}, 10^{4}\right.$ and $10^{5}$ per each type) were injected s.c. into three 4-6 weeks old female NOD/SCID mice with body weight of 17-24 g (Shanghai Slac Laboratory Animal Co., Ltd., Shanghai, China), respectively. 
Table I. Primers and cycle numbers used in RT-PCR analysis.

\begin{tabular}{llll}
\hline Primer name & & \multicolumn{1}{c}{ Primer sequence from 5' to 3' } & PCR cycles \\
\hline GAPDH & Sense: & 5'-CCACCCATGGCAAATTCCATGGCA-3' \\
& Antisense: & 5'-TCTAGACGGCAGGTCAGGTCCACC-3' \\
ALPI & Sense: & 5'-TTCCCATACCTGGCTCTGTC-3' \\
& Antisense: & 5'-TGAGTACCAGTTGCGGTTCA-3' \\
ABCG2 & Sense: & 5'-TGTGGAGGAACTGGGTAGGA-3' \\
& Antisense: & 5'-AAGCCATTGGTGTTTCCTTG-3' \\
WNT5A & Sense: & 5'-CTCGCCATGAAGAAGTCCAT-3' \\
& Antisense: & 5'-CCTTCGATGTCGGAATTGAT-3' \\
BNC1 & Sense: & 5'-AACCCGGGAAAATAAACCAC-3' \\
& Antisense: & 5'-ATGATGCACCAGTGATCCAA-3' \\
IGFBP3 & Sense: & 5'-ACAGCCAGCGCTACAAAGTT-3' \\
& Antisense: & 5'-AGGCTGCCCATACTTATCCA-3' \\
SCEL & Sense: & 5'-GTGGTGCTCAACCGACATAA-3' \\
& Antisense: & 5'-TGCTCGAAGAGGCATTGTAA-3' \\
\hline
\end{tabular}

All the mice were sacrificed 6-16 weeks after injection and examined for tumors. The tumor blocks were dissected and made into tissue sections for inspection. Tumor blocks were dissected and fixed by immersion in $4 \%$ paraformaldehyde phosphate buffer. After fixation for 2-4 h, tissues were dehydrated, paraffin- embedded, sectioned at $4 \mu \mathrm{m}$ and stained with haematoxylin and eosin (HE) for histological examination.

Microarray analysis. Microarray analysis was performed as previously described (51). GeneChip Human Genome U133 Plus 2.0 was used to analyze the gene expression profile of $\mathrm{ABCG}^{+}$cells and ABCG2- cells. The chip covers 47,400 transcripts and contains 38,500 known human genes. A probe hits only one genomic location; probes that can be mapped to the same target sequence in the correct direction are grouped together in the same probe set; each probe set consists of 10-20 pairs of 25 mer probes; each probe pair consists of two probe cells, one of which is perfect match and another of which is mismatch containing one base mismatch. The gene sequences are selected from GenBank, dbEST and RefSeq.

Total RNA of $\mathrm{ABCG}^{+}$cells and $\mathrm{ABCG} 2^{-}$cells was extracted and used to purify polyA ${ }^{+}$mRNA. The cDNA, double strand DNA and biotin-labled cRNA were synthesized in turn. After fragmented, the labled cRNA was loaded on the gene chip for microarray analysis. Hybridization, elution and staining of the chip were conducted with Affymetrix Hybridization Oven 640 and Affymetrix Fluidics Station 450 according to the manufacturer's instruction. After the chips were scanned, GCOS data processing software was used to calculate and process the obtained data. Before comparison of the results of two chips, the data of each chip were normalized to obtain reporter signal value. For screening the differentially expressed genes between $\mathrm{ABCG} 2^{+}$and $\mathrm{ABCG} 2^{-}$group, signal $\log$ ratio $\geq 1.0$ or $\leq-1.0$ (indicating 2 -fold upregulation or downregulation of gene expression level) was set as screening criterion.
Verification of differentially expressed genes by RT-PCR. $\mathrm{ABCG}^{+}$and $\mathrm{ABCG} 2^{-}$cells were harvested, respectively. Total RNAs were extracted from the harvested cells with TRIzol reagent according to the manufacturer's protocols and subsequently digested with DNase I to remove the residual amount of genomic DNA. RT-PCR was carried out with AMV reverse transcriptase system to detect the expression of selected genes. The PCR conditions were as follows: $3 \mathrm{~min}$ at $95^{\circ} \mathrm{C}$; $40 \mathrm{sec}$ at $94^{\circ} \mathrm{C}, 30 \mathrm{sec}$ at $55-58^{\circ} \mathrm{C}$ and $50 \mathrm{sec}$ at $72^{\circ} \mathrm{C}$ for appropriate cycles; $10 \mathrm{~min}$ at $72^{\circ} \mathrm{C}$ for extension. GAPDH was used as internal control. The used PCR primers and cycle number are shown in Table I. RT-PCR product bands were scanned with image analyzer (Pharmacia, USA) and the accumulated optical density value (IA) of each band was analyzed with Imagemaster VDS software.

Geneontology analysis. GOSTAT (http://gostat.wehi.edu.au) was used to analyze and annotate the differentially expressed genes. GO provides three kinds of specifying terminology to describe the characteristics of gene products, including molecular function, biological process and cellular component.

Statistical analysis. SPSS13.0 statistical software and one-way ANOVA were used to analyze the cloning efficiency data. GCOS was used to test gene expression level of ABCG2+ and $\mathrm{ABCG} 2^{-}$group and rank-test was applied to define the determinant interval. A P-value $<0.05$ was considered to be statistically significant.

\section{Results}

Double labeling detection of LRC and ABCG2 expression in 5-8F cells. 5-8F NPC cells were labeled with BrdU, inoculated into nude mice, traced for 8 weeks and then detected for LRC and $\mathrm{ABCG} 2$ expression. In LRCs, there was $61.69 \pm 8.31 \%$ $(\mathrm{n}=3)$ of $\mathrm{ABCG} 2^{+}$cells, while in $\mathrm{ABCG} 2^{+}$cells, there was $12.05 \pm 2.80 \%(n=3)$ of LRCs (Table II, Fig. 1). 

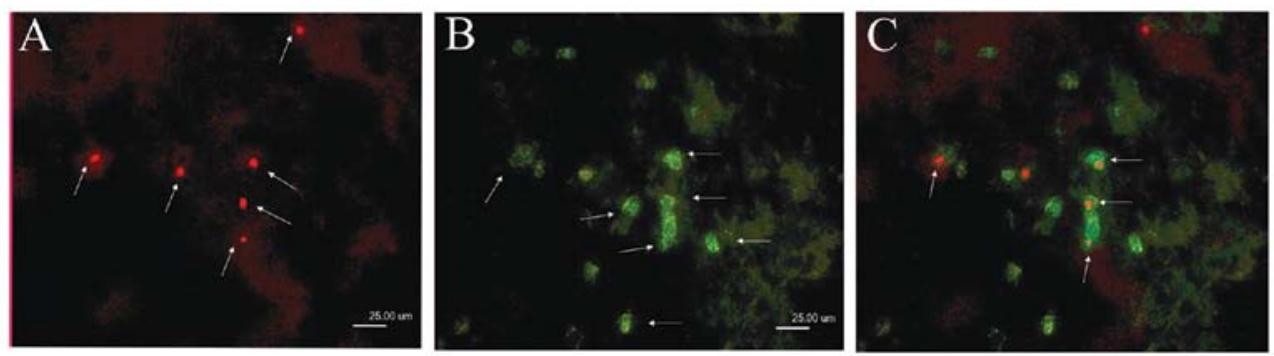

Figure 1. Detection of LRCs and ABCG2 expression in NPC tissues. (A) Detection of LRCs. Arrows indicate BrdU positive cells. (B) Detection of ABCG2 expression. Arrows indicate ABCG2 positive cells. (C) Double labeling for LRCs and ABCG2 expression. Arrows indicate double labeled cells. Red BrdU signals are concentrated in nuclei, while green ABCG2 signals are concentrated on cell membrane and in the cytoplasm.

Table II. Results of double labeling detection for LRCs and ABCG2 expression.

\begin{tabular}{lcc}
\hline & $\begin{array}{c}\text { DLCs/LRCs } \\
(\%)\end{array}$ & $\begin{array}{c}\text { DLCs/ABCG2 } \\
\text { cells (\%) }\end{array}$ \\
\hline Xenografted nude mouse 1 & 60.12 & 9.64 \\
Xenografted nude mouse 2 & 54.28 & 11.38 \\
Xenografted nude mouse 3 & 70.67 & 15.12 \\
Mean \pm SD & $61.69 \pm 8.31$ & $12.05 \pm 2.80$ \\
\hline
\end{tabular}

DLCs, double labeled cells.

Sorting $A B C G 2^{+}$cells by MACS from 5-8F cells. 5-8F NPC cells were cultured and harvested, labeled with ABCG2 antibody and magnetic beads, and then sorted through MS sorting column. The rate of $\mathrm{ABCG}_{2}+$ cells was $2.11 \pm 0.36 \%(\mathrm{n}=5)$. The $\mathrm{ABCG} 2^{+}$and $\mathrm{ABCG} 2^{-}$cells were smeared on slides, respectively and detected for ABCG2 expression with immunocytochemistry methods. $\mathrm{ABCG} 2$ was highly expressed in $\mathrm{ABCG} 2^{+}$ cells, the positive signals located on the cell membrane and the purity of $\mathrm{ABCG}^{+}$cells reached $90.73 \%$. ABCG2 was weakly expressed in only a minority of ABCG2 cells (Fig. 2A and B). After labeled with IgG-FITC, $\mathrm{ABCG}^{+}$and $\mathrm{ABCG} 2^{-}$cells were analyzed by flow cytometry. It was shown that the purity of $\mathrm{ABCG}^{+}$cells was $95.93 \%$ (Fig. 2C-E). These data showed that we had successfully enriched $\mathrm{ABCG} 2^{+}$cells.

Identification of biological characteristics of $\mathrm{ABCG}^{+}$cells. $\mathrm{ABCG}^{+}, \mathrm{ABCG} 2^{-}$and unsorted $5-8 \mathrm{~F}$ cells were analyzed by flow cytometry, respectively. As seen in Fig. 3A-C and Table III, the rate of G0/G1 phase cells was the highest (73.74\%) in $\mathrm{ABCG}_{2}{ }^{+}$cells among these three types of cells and the rate of S phase cells was the highest (32.56\%) in ABCG2- cells, indicating that $\mathrm{ABCG} 2^{+}$cells were mostly quiescent and more ABCG2- cells were in DNA synthesis period. Therefore, some of the ABCG2 cells might be the transient amplifying cells that could proliferate rapidly.

Cloning efficiency was analyzed among $\mathrm{ABCG} 2^{+}$, ABCG2 and unsorted 5-8F cells. The $\mathrm{ABCG}^{+}$cells formed smaller number of colonies compared with ABCG2- cells and unsorted $5-8 \mathrm{~F}$ cells $(\mathrm{P}<0.05)$, while the formed colony number of $\mathrm{ABCG} 2^{-}$cells was higher than that of $5-8 \mathrm{~F}$ cells $(\mathrm{P}<0.05)$ (Fig. 3D and E, Table IV).
Table III. Cell cycle distribution of $\mathrm{ABCG}^{+}, \mathrm{ABCG} 2^{-}$and unsorted 5-8F cells.

\begin{tabular}{lccc}
\hline & \multicolumn{3}{c}{ Cell cycle distribution (\%) } \\
\cline { 2 - 4 } Cells & $\mathrm{G} 0+\mathrm{G} 1$ & $\mathrm{~S}$ & $\mathrm{G} 2+\mathrm{M}$ \\
\hline ABCG2 $^{+}$ & 73.74 & 20.92 & 5.34 \\
ABCG2 $^{-}$ & 60.37 & 32.56 & 7.07 \\
Unsorted 5-8F & 62.92 & 28.43 & 8.65 \\
\hline
\end{tabular}

Table IV. Comparison of colony-forming capacity of $\mathrm{ABCG} 2^{+}$, ABCG2 ${ }^{-}$and unsorted 5-8F cells.

\begin{tabular}{cccc}
\hline & ABCG2 $^{+}$ & ABCG2 & 5-8F \\
\hline Colony no. & $42,48,49$ & $115,129,132$ & $77,86,88$ \\
& $46,49,57$ & $104,122,129$ & $69,78,82$ \\
& $33,48,49$ & $112,118,125$ & $80,83,91$ \\
Mean \pm SD $^{\mathrm{a}}$ & $46.78 \pm 6.48$ & $120.67 \pm 9.22$ & $81.56 \pm 6.58$ \\
\hline
\end{tabular}

${ }^{\text {aThe }}$ is significant difference between the data of any two groups $(\mathrm{P}<0.05)$.

To compare the tumorigenicity of $\mathrm{ABCG}^{+}, \mathrm{ABCG}^{-}$and unsorted 5-8F cells, we inoculated these cells into NOD/SCID mice, respectively. When inoculated with $10^{2}-10^{4}$ cells, tumor formation could not be observed even after 113 days in either group. When inoculated with $10^{5}$ cells, tumor block could be seen after 12 days in $\mathrm{ABCG} 2^{-}$cell group and 5-8F cell group and after 20 days in $\mathrm{ABCG}^{+}$cell group. The weight of tumor blocks was highest in ABCG2- cell group and lowest in $\mathrm{ABCG}^{+}$cell group (Fig. 3F, Table V). Tumor formation rate was lowest in $\mathrm{ABCG} 2^{+}$cell group (2/3) and was $100 \%$ (3/3) in other two groups. Paraffin sections were prepared from these tumor blocks and detected by H\&E staining. The morphology of tumor cells from these three groups exhibited no significant difference (Fig. 3G-I).

Gene expression profile of $A B C G 2^{+}$and $A B C G 2^{-}$cells. Affymetrix oligonucleotide microarray (Human Genome U133 Plus 2.0 Array) was used to monitor gene expression of about 

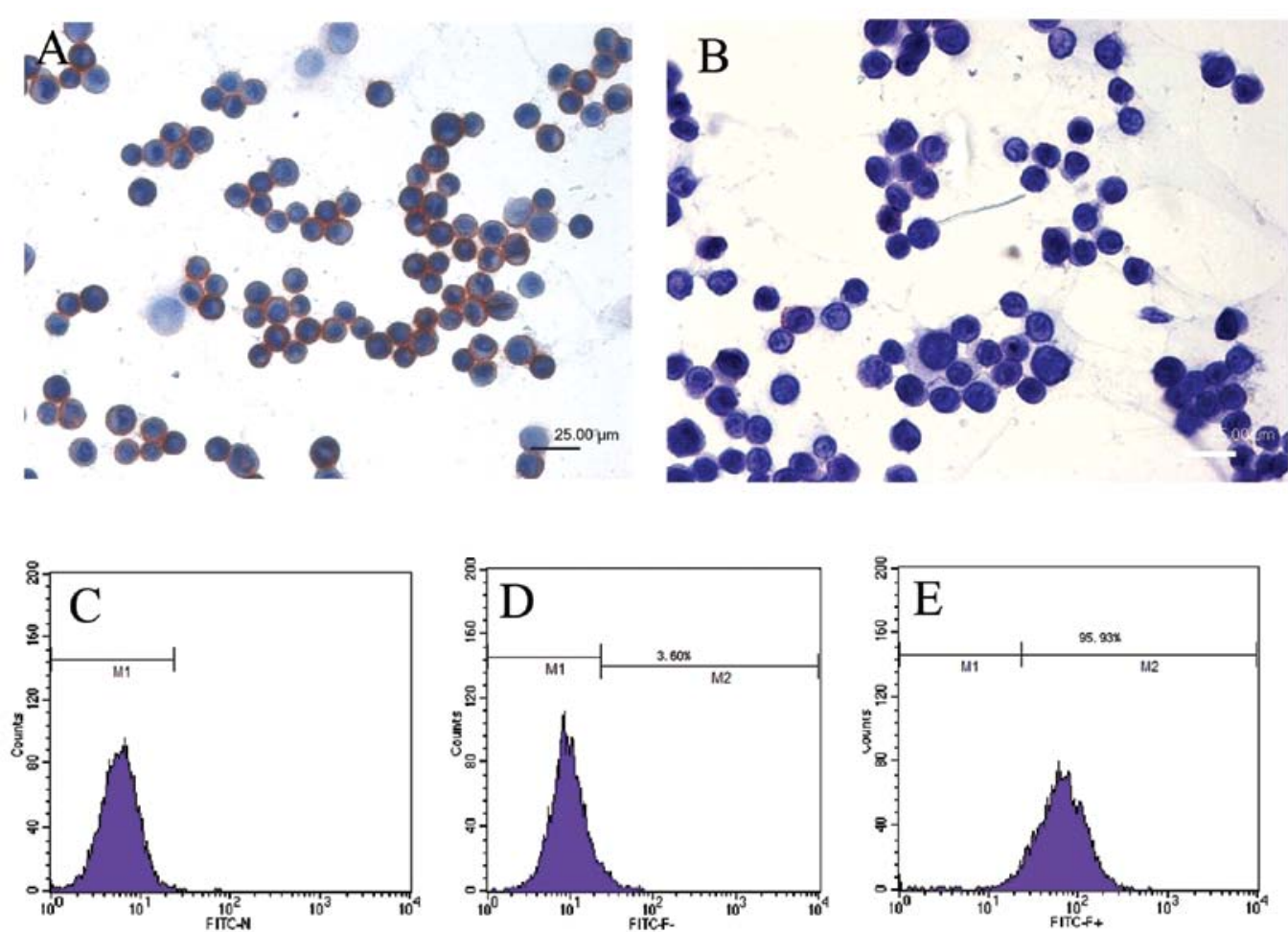

Figure 2. Verification of sorted cells by immunocytochemistry (A and B) and flow cytometry (C-E). ABCG2 is expressed only in ABCG2+ cells (A) but not in ABCG2 cells (B). (C-E) Indicate measurement of ABCG2 expression by flow cytometry in 5-8F cells (C), ABCG2- cells (D) and ABCG2 ${ }^{+}$cells (E), respectively. The purity of sorted $\mathrm{ABCG}^{+}$cells is $95.93 \%$.

Table V. Tumors formed by dorsal subcutaneous inoculation of $\mathrm{ABCG}^{+}, \mathrm{ABCG}^{-}$and unsorted 5-8F cells into NOD/SCID mice.

\begin{tabular}{|c|c|c|c|c|}
\hline Cells & Cell no. & Tumor formation rate & Tumor weight (g) & Latency period (day) \\
\hline \multirow[t]{4}{*}{$\mathrm{ABCG}^{+}$} & $1 \times 10^{2}$ & - & & \\
\hline & $1 \times 10^{3}$ & - & & \\
\hline & $1 \times 10^{4}$ & - & & \\
\hline & $1 \times 10^{5}$ & $2 / 3$ & $0.93,0.17$ & 20,29 \\
\hline \multirow[t]{4}{*}{ ABCG2- } & $1 \times 10^{2}$ & - & & \\
\hline & $1 \times 10^{3}$ & - & & \\
\hline & $1 \times 10^{4}$ & - & & \\
\hline & $1 \times 10^{5}$ & $3 / 3$ & $2.44,3.95,2.29$ & $12,14,14$ \\
\hline \multirow[t]{4}{*}{ Unsorted 5-8F } & $1 \times 10^{2}$ & - & & \\
\hline & $1 \times 10^{3}$ & - & & \\
\hline & $1 \times 10^{4}$ & - & & \\
\hline & $1 \times 10^{5}$ & $3 / 3$ & $2.96,1.43,1.69$ & $12,13,15$ \\
\hline
\end{tabular}

47,400 transcripts containing 38,500 known genes in $\mathrm{ABCG}^{+}$ and $\mathrm{ABCG} 2^{-}$cells. After the differential gene expression profiles between $\mathrm{ABCG}^{+}$and $\mathrm{ABCG} 2^{-}$cells were constructed, differentially expressed genes or ESTs which were upregulated (for 2 fold) or downregulated (for 2 fold) were screened. There were 353 genes or ESTs upregulated significantly in $\mathrm{ABCG}^{+}$cells and 590 genes or ESTs upregulated significantly in ABCG2 cells out of the 47,400 transcripts. The 80 most significantly differentially expressed genes in $\mathrm{ABCG}^{+}$and $\mathrm{ABCG} 2^{-}$cells are listed in Table VI.
Differentially expressed genes were analyzed by Gene Ontology. A group of genes generally involved in negative regulation of cell cycle progression were discovered in $\mathrm{ABCG}^{+}$cells, whereas this functional classification could not be found in $\mathrm{ABCG} 2^{-}$cells, which can explain the fact that most $\mathrm{ABCG} 2^{+}$cells were in G0/G1 phase of cell cycle. The stem cell associated genes PSCA, ABCG2 and ALPI were upregulated significantly in $\mathrm{ABCG} 2^{+}$cells, while another set of stem cell related genes including K19, integrin $\alpha 6$, integrin $\beta 4$, CD44 and K14 were upregulated significantly in ABCG2- 
Table VI. Eighty most differentially expressed genes in $\mathrm{ABCG}^{+}$and $\mathrm{ABCG} 2^{-}$cells

\begin{tabular}{|c|c|c|c|c|}
\hline $\begin{array}{l}\text { Gene } \\
\text { symbol }\end{array}$ & $\mathrm{SLR}^{\mathrm{a}}$ & $\begin{array}{l}\text { UniGene } \\
\text { ID }\end{array}$ & Gene title & $\begin{array}{l}\text { Chromosomal } \\
\text { location }\end{array}$ \\
\hline $\mathrm{A} 2 \mathrm{M}$ & 6.4 & Hs. 212838 & $\alpha$-2-macroglobulin & $\operatorname{chr} 12 \mathrm{p} 13.3-\mathrm{p} 12.3$ \\
\hline ALPI & 5.9 & Hs.37009 & Alkaline phosphatase, intestinal & $\operatorname{chr} 2 \mathrm{q} 37.1$ \\
\hline CGA & 5.7 & Hs.119689 & Glycoprotein hormones, $\alpha$ polypeptide & chr6q12-q21 \\
\hline SLC16A6 & 5.3 & Hs.42645 & Solute carrier family 16, member 6 & $\operatorname{chr} 17 q 24.2$ \\
\hline DAB2 & 5.2 & Hs.481980 & Disabled homolog 2, mitogen-responsive phosphoprotein & $\operatorname{chr} 5 \mathrm{p} 13$ \\
\hline C1QTNF6 & 4.9 & Hs.22011 & $\mathrm{C} 1 \mathrm{q}$ and tumor necrosis factor related protein 6 & $\operatorname{chr} 22 q 13.1$ \\
\hline SNAP25 & 4.6 & Hs.167317 & Synaptosomal-associated protein, $25 \mathrm{kDa}$ & chr20p12-p11.2 \\
\hline $\mathrm{DIO} 2$ & 4.4 & Hs.202354 & Deiodinase, iodothyronine, type II & $\operatorname{chr} 14 q 24.2-q 24.3$ \\
\hline CTGF & 4.1 & Hs.410037 & Connective tissue growth factor & chr6q23.1 \\
\hline ECG2 & 4.1 & Hs.244569 & Esophagus cancer-related gene- 2 & chr5q32 \\
\hline PDE3A & 4.1 & Hs.386791 & Phosphodiesterase 3A, cGMP-inhibited & $\operatorname{chr} 12 \mathrm{p} 12$ \\
\hline TFPI & 4.0 & Hs.516578 & $\begin{array}{l}\text { Tissue factor pathway inhibitor (lipoprotein-associated } \\
\text { coagulation inhibitor) }\end{array}$ & chr2q31-q32.1 \\
\hline ADAM12 & 4.0 & Hs.386283 & ADAM metallopeptidase domain 12 (meltrin $\alpha)$ & $\operatorname{chr} 10 q 26.3$ \\
\hline C6orf176 & 3.9 & Hs.31917 & Chromosome 6 open reading frame 176 & chr6q27 \\
\hline EID3 & 3.9 & - & E1A-like inhibitor of differentiation 3 & $\operatorname{chr} 12 q 23-q 24.1$ \\
\hline DUSP1 & 3.8 & Hs.171695 & Dual specificity phosphatase 1 & $\operatorname{chr} 5 \mathrm{q} 34$ \\
\hline PCSK1 & 3.6 & Hs.78977 & Proprotein convertase subtilisin/kexin type 1 & $\operatorname{chr} 5 q 15-q 21$ \\
\hline PRO0132 & 3.6 & - & PRO0132 protein & $\operatorname{chr} 2 \mathrm{q} 34$ \\
\hline SLC16A6 & 3.6 & Hs.463838 & Solute carrier family 16 , member 6 & $\operatorname{chr} 17 \mathrm{q} 24.2$ \\
\hline MRS2L & 3.4 & Hs.533291 & MRS2-like, magnesium homeostasis factor & chr6p22.3-p22.1 \\
\hline SLC29A3 & 3.3 & Hs.438419 & Solute carrier family 29, member 3 & $\operatorname{chr} 10 \mathrm{q} 22.1$ \\
\hline PRG1 & 3.2 & Hs.1908 & Proteoglycan 1 , secretory granule & chr10q22.1 \\
\hline CES1 & 3.2 & Hs.535486 & Carboxylesterase 1 & chr16q13-q22.1 \\
\hline UGT1A8 & 3.2 & - & UDP glucuronosyltransferase 1 family, polypeptide A8 & $\operatorname{chr} 2 \mathrm{q} 37$ \\
\hline APOC3 & 3.1 & Hs.534984 & Apolipoprotein C-III & $\operatorname{chr} 11 \mathrm{q} 23.1-\mathrm{q} 23.2$ \\
\hline ABCG2 & 3.1 & Hs.480218 & ATP-binding cassette, sub-family G, member 2 & $\operatorname{chr} 4 \mathrm{q} 22$ \\
\hline FYN & 3.1 & Hs.390567 & FYN oncogene related to SRC, FGR, YES & chr6q21 \\
\hline WNT5A & 3.1 & Hs. 152213 & Wingless-type MMTV integration site family, member 5A & chr3p21-p14 \\
\hline FOSB & 3.0 & Hs.75678 & FBJ murine osteosarcoma viral oncogene homolog B & $\operatorname{chr19q13.32}$ \\
\hline PAPSS2 & 3.0 & Hs.524491 & 3'-Phosphoadenosine 5'-phosphosulfate synthase 2 & chr10q23-q24 \\
\hline VTN & 3.0 & Hs. 2257 & Vitronectin & $\operatorname{chr17q11}$ \\
\hline CPS1 & 3.0 & Hs.149252 & Carbamoyl-phosphate synthetase 1 & $\operatorname{chr} 2 q 35$ \\
\hline RHOBTB1 & 3.0 & Hs. 148670 & Rho-related BTB domain containing 1 & $\operatorname{chr} 10 \mathrm{q} 21.2$ \\
\hline FTO & 3.0 & Hs.528833 & Fatso & $\operatorname{chr} 16 \mathrm{q} 12.2$ \\
\hline TBX3 & 3.0 & Hs.129895 & T-box 3 & $\operatorname{chr} 12 q 24.1$ \\
\hline C20orf100 & 3.0 & Hs.26608 & Chromosome 20 open reading frame 100 & chr20q13.12 \\
\hline BMP2 & 2.9 & Hs.73853 & Bone morphogenetic protein 2 & chr20p12 \\
\hline PPP1R15A & 2.8 & Hs.76556 & Protein phosphatase 1 , regulatory (inhibitor) subunit $15 \mathrm{~A}$ & $\operatorname{chr} 19 q 13.2$ \\
\hline MX1 & 2.8 & Hs.517307 & Myxovirus resistance 1 & $\operatorname{chr} 21 q 22.3$ \\
\hline PAPSS2 & 2.8 & Hs.524491 & 3'-Phosphoadenosine 5'-phosphosulfate synthase 2 & chr10q23-q24 \\
\hline IF & -3.2 & Hs.312485 & I factor (complement) & $\operatorname{chr} 4 \mathrm{q} 25$ \\
\hline TBX18 & -3.2 & Hs. 251830 & T-box 18 & chr6q14-q15 \\
\hline ITGB4 & -3.2 & Hs.370255 & Integrin, $\beta 4$ & $\operatorname{chr} 17 \mathrm{q} 25$ \\
\hline SLCO1B3 & -3.2 & Hs.504966 & Solute carrier organic anion transporter family, member 1B3 & $\operatorname{chr} 12 \mathrm{p} 12$ \\
\hline CD300LG & -3.3 & Hs. 147313 & CD300 antigen like family member $\mathrm{G}$ & $\operatorname{chr} 17 \mathrm{q} 21.31$ \\
\hline GJA1 & -3.3 & Hs.74471 & Gap junction protein, $\alpha 1,43 \mathrm{kDa}$ (connexin 43) & chr6q21-q23.2 \\
\hline FLI1 & -3.4 & Hs.504281 & Friend leukemia virus integration 1 & chr11q24.1-q24.3 \\
\hline IGFBP3 & -3.4 & Hs.450230 & Insulin-like growth factor binding protein 3 & chr7p13-p12 \\
\hline GABRB1 & -3.4 & Hs.27283 & $\gamma$-aminobutyric acid (GABA) A receptor, $\beta 1$ & chr4p12 \\
\hline LUM & -3.5 & Hs.406475 & Lumican & $\operatorname{chr} 12 q 21.3-q 22$ \\
\hline
\end{tabular}


Table VI. Continued.

\begin{tabular}{|c|c|c|c|c|}
\hline $\begin{array}{l}\text { Gene } \\
\text { symbol }\end{array}$ & $\mathrm{SLR}^{\mathrm{a}}$ & $\begin{array}{l}\text { UniGene } \\
\text { ID }\end{array}$ & Gene title & $\begin{array}{l}\text { Chromosomal } \\
\text { location }\end{array}$ \\
\hline CALB1 & -3.5 & Hs.65425 & Calbindin $1,28 \mathrm{kDa}$ & chr8q21.3-q22.1 \\
\hline TP73L & -3.5 & Hs.137569 & Tumor protein p73-like & $\operatorname{chr} 3 q 28$ \\
\hline DSG3 & -3.5 & Hs. 1925 & Desmoglein 3 (pemphigus vulgaris antigen) & $\operatorname{chr} 18 \mathrm{q} 12.1-\mathrm{q} 12.2$ \\
\hline PPP1R14C & -3.6 & Hs.486798 & Protein phosphatase 1 , regulatory (inhibitor) subunit $14 \mathrm{C}$ & $\operatorname{chr} 6 \mathrm{q} 24.3-\mathrm{q} 25.3$ \\
\hline OR5K1 & -3.7 & Hs.531371 & Olfactory receptor, family 5 , subfamily $\mathrm{K}$, member 1 & $\operatorname{chr} 3 q 12.1$ \\
\hline GPR87 & -3.7 & Hs. 58561 & G protein-coupled receptor 87 & $\operatorname{chr} 3 \mathrm{q} 24$ \\
\hline RSAD2 & -3.7 & Hs. 17518 & Radical S-adenosyl methionine domain containing 2 & $\operatorname{chr} 2 \mathrm{p} 25.2$ \\
\hline EGLN3 & -3.8 & Hs. 135507 & Egl nine homolog 3 (C. elegans) & $\operatorname{chr} 14 q 13.1$ \\
\hline CLCA2 & -3.9 & Hs.241551 & Chloride channel, calcium-activated, family member 2 & chr1p31-p22 \\
\hline FST & -3.9 & Hs.9914 & Follistatin & $\operatorname{chr} 5 q 11.2$ \\
\hline LOC196264 & -4.0 & Hs.15396 & Hypothetical protein LOC196264 & $\operatorname{chr} 11 \mathrm{q} 23.3$ \\
\hline DSC3 & -4.0 & Hs.41690 & Desmocollin 3 & chr18q12.1 \\
\hline KRT14 & -4.0 & Hs.355214 & $\begin{array}{l}\text { Keratin } 14 \text { (epidermolysis bullosa simplex, } \\
\text { Dowling-Meara, Koebner) }\end{array}$ & $\operatorname{chr} 17 q 12-q 21$ \\
\hline PDCD8 & -4.0 & Hs.424932 & Programmed cell death 8 (apoptosis-inducing factor) & $\operatorname{chrXq25-q26}$ \\
\hline PRSS35 & -4.0 & Hs.98381 & Protease, serine, 35 & chr6q14.2 \\
\hline BNC1 & -4.1 & Hs.459153 & Basonuclin 1 & $\operatorname{chr} 15 \mathrm{q} 25.2$ \\
\hline ITGB6 & -4.1 & Hs.470399 & Integrin, $\beta 6$ & $\operatorname{chr} 2 q 24.2$ \\
\hline SCEL & -4.1 & Hs.492938 & Sciellin & $\operatorname{chr} 13 \mathrm{q} 22$ \\
\hline LAMC2 & -4.2 & Hs.530509 & Laminin, $\gamma 2$ & $\operatorname{chr} 1 \mathrm{q} 25-\mathrm{q} 31$ \\
\hline PDZK3 & -4.2 & Hs.481819 & PDZ domain containing 3 & $\operatorname{chr} 5 \mathrm{p} 13.3$ \\
\hline GABRA2 & -4.3 & Hs. 116250 & $\gamma$-aminobutyric acid (GABA) A receptor, $\alpha 2$ & $\operatorname{chr} 4 \mathrm{p} 12$ \\
\hline LAMB4 & -4.4 & Hs.62022 & Laminin, $\beta 4$ & $\operatorname{chr} 7 \mathrm{q} 22-\mathrm{q} 31.2$ \\
\hline KRT19 & -4.5 & Hs.514167 & Keratin 19 & $\operatorname{chr} 17 \mathrm{q} 21.2$ \\
\hline DSG3 & -4.5 & Hs.1925 & Desmoglein 3 (pemphigus vulgaris antigen) & $\operatorname{chr} 18 \mathrm{q} 12.1-\mathrm{q} 12.2$ \\
\hline ITGB4 & -4.6 & Hs.370255 & Integrin, $\beta 4$ & $\operatorname{chr} 17 \mathrm{q} 25$ \\
\hline ROCK1 & -4.7 & Hs.306307 & Rho-associated, coiled-coil containing protein kinase 1 & chr18q11.1 \\
\hline IGFBP7 & -4.8 & Hs.479808 & Insulin-like growth factor binding protein 7 & $\operatorname{chr} 4 q 12$ \\
\hline IGFBP3 & -4.8 & Hs. 450230 & Insulin-like growth factor binding protein 3 & chr7p13-p12 \\
\hline LIFR & -4.8 & Hs.133421 & Leukemia inhibitory factor receptor & chr5p13-p12 \\
\hline IL1A & -5.5 & Hs.1722 & Interleukin $1, \alpha$ & $\operatorname{chr} 2 q 14$ \\
\hline
\end{tabular}

${ }^{\mathrm{a}} \mathrm{SLR}, \mathrm{ABCG}^{+}{ }^{+}$vs. ABCG2- signal log ratio.

cells, suggesting that there are stem cells in both $\mathrm{ABCG} 2^{+}$and ABCG2 cells.

From the chip analysis results, we selected 6 meaningful genes such as ALPI, ABCG2 and WNT5A which were highly expressed in $\mathrm{ABCG}^{+}$cells, and $\mathrm{BNC1}$, IGFBP3 and SCEL which were highly expressed in $\mathrm{ABCG} 2^{-}$cells to perform RT-PCR verification. The expression of these genes was consistent with the results of chip analysis (Fig. 4A and B).

Fig. 4C exhibited the scatterplot of average expression value in $\mathrm{ABCG}^{+}$and $\mathrm{ABCG} 2^{-}$cells. The $\mathrm{x}$-axis showed the signals of $\mathrm{ABCG} 2^{-}$cell group and the $\mathrm{y}$-axis showed the signals of $\mathrm{ABCG}^{+}$cell group. Red plots indicated genes whose detection results were $\mathrm{P}$ (present) in two groups, blue blots indicated genes whose detection results were $\mathrm{P}$ in only one of the two groups and yellow plots represented genes whose detection results were A (absent) in both groups. From top to bottom, the green oblique lines represented expression difference at $30,10,4,2,1 / 2,1 / 4,1 / 10$ and 1/30-fold between $\mathrm{ABCG} 2^{+}$and ABCG2- cells, respectively. The result demonstrated that the expression difference of most genes between $\mathrm{ABCG} 2^{+}$and ABCG2- cells was 2- to 4-fold and that only a minority of the genes could reach 10 - to 30 -fold or above.

\section{Discussion}

Previously we have shown that LRCs exist in nasopharynx, tongue, esophagus and xenograft NPC tissues (49). One of the characteristics of adult stem cells is that they can be labeled for a long time and therefore are known as LRCs (52). Label retaining experiment is an effective method to label and detect stem cells in tissue of living organism (53). BrdU and $3 \mathrm{H}$-thymine deoxyribose (3H-TdR) are commonly 

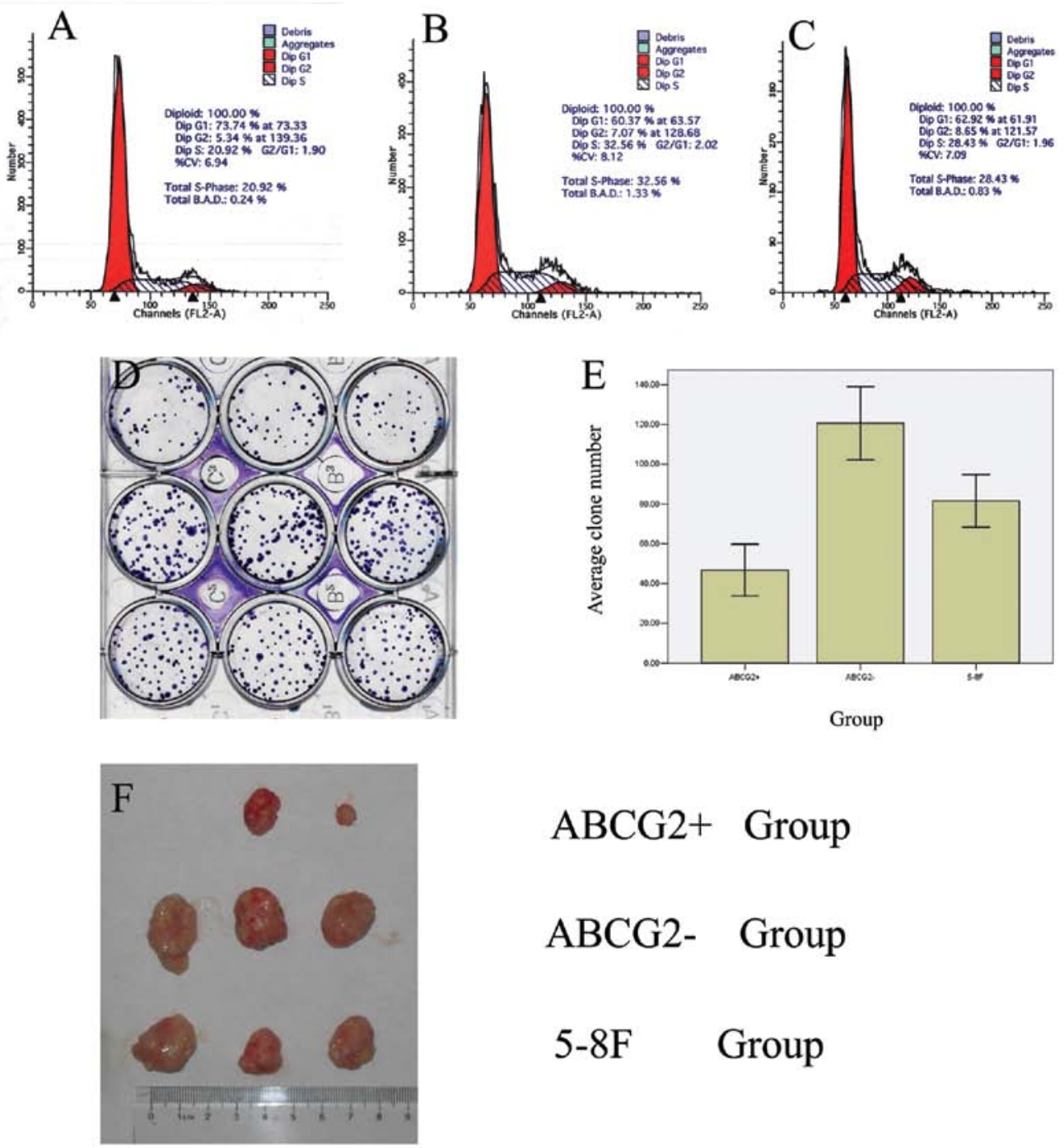

ABCG2+ Group

ABCG2- Group

5-8F Group
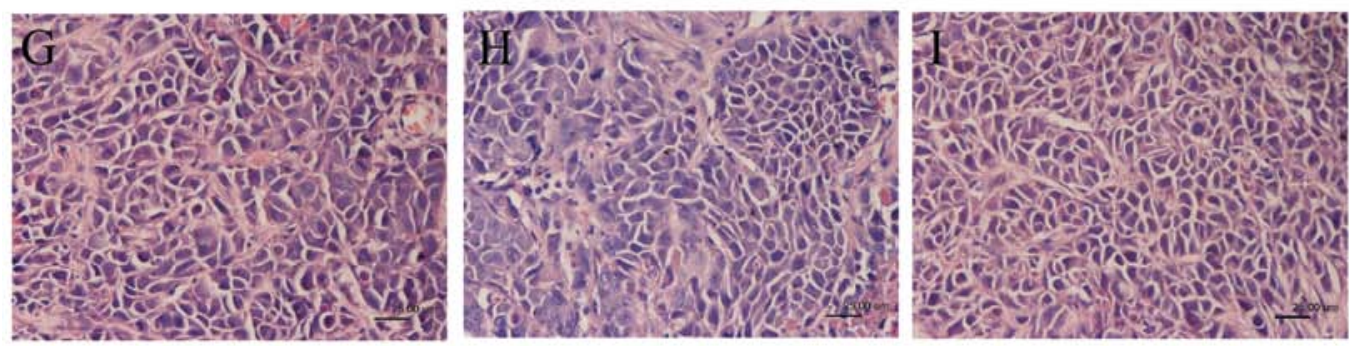

Figure 3. Biological characteristics of ABCG2+ cells. (A-C) The cell cycle distribution of ABCG2+, ABCG2- and unsorted 5-8F cells, respectively. (D) Colonies formed by $\mathrm{ABCG}^{+}$cells (upper row), ABCG2 cells (middle row) and 5-8F cells (lower row). Each kind of cells was inoculated into 3 wells at 200 cells per well. After 14 days, the colonies were stained with crystal violet and then observed and counted. (E) Colony formation rate with bar chart. (F) The tumor blocks formed by inoculation of $\mathrm{ABCG}^{+}, \mathrm{ABCG} 2^{-}$and $5-8 \mathrm{~F}$ cells into NOD/SCID mice. (G-I) H\&E staining of tissue sections made from xenograft tumors formed by inoculation of $\mathrm{ABCG}^{+}$cells (G), ABCG2 cells (H) and 5-8F cells (I) into NOD/SCID mice.

used labeling markers. The mechanism underlying the label retaining of a marker in stem cells is unclear. One explanation is that stem cells exhibit slow cell cycle progression, therefore the marker can remain in DNA of LRCs after tracing for a long time, while the marker in other cells will be gradually diluted with rapid cell division. Cairns (54) raised another explanation for LRC. Because of the asymmetry of stem cell division, labeled DNA is always allocated to daughter stem cells and the newly synthesized DNA is always allocated to daughter differentiated cells. We consider that the above explanations can partly explain the mechanism of the label retaining characteristic of stem cells.

In this study, we first labeled the cells in NPC tissue formed by inoculation of $5-8 \mathrm{~F}$ cells into nude mice. Although scarce, the existence of LRCs indicated that there were cancer stem cells in NPC tissue. To further identify these LRCs, we detected the expression of ABCG2 in the same NPC tissue. ABCG2, a member of $\mathrm{ABC}$ transporter superfamily, is a transmembrane 

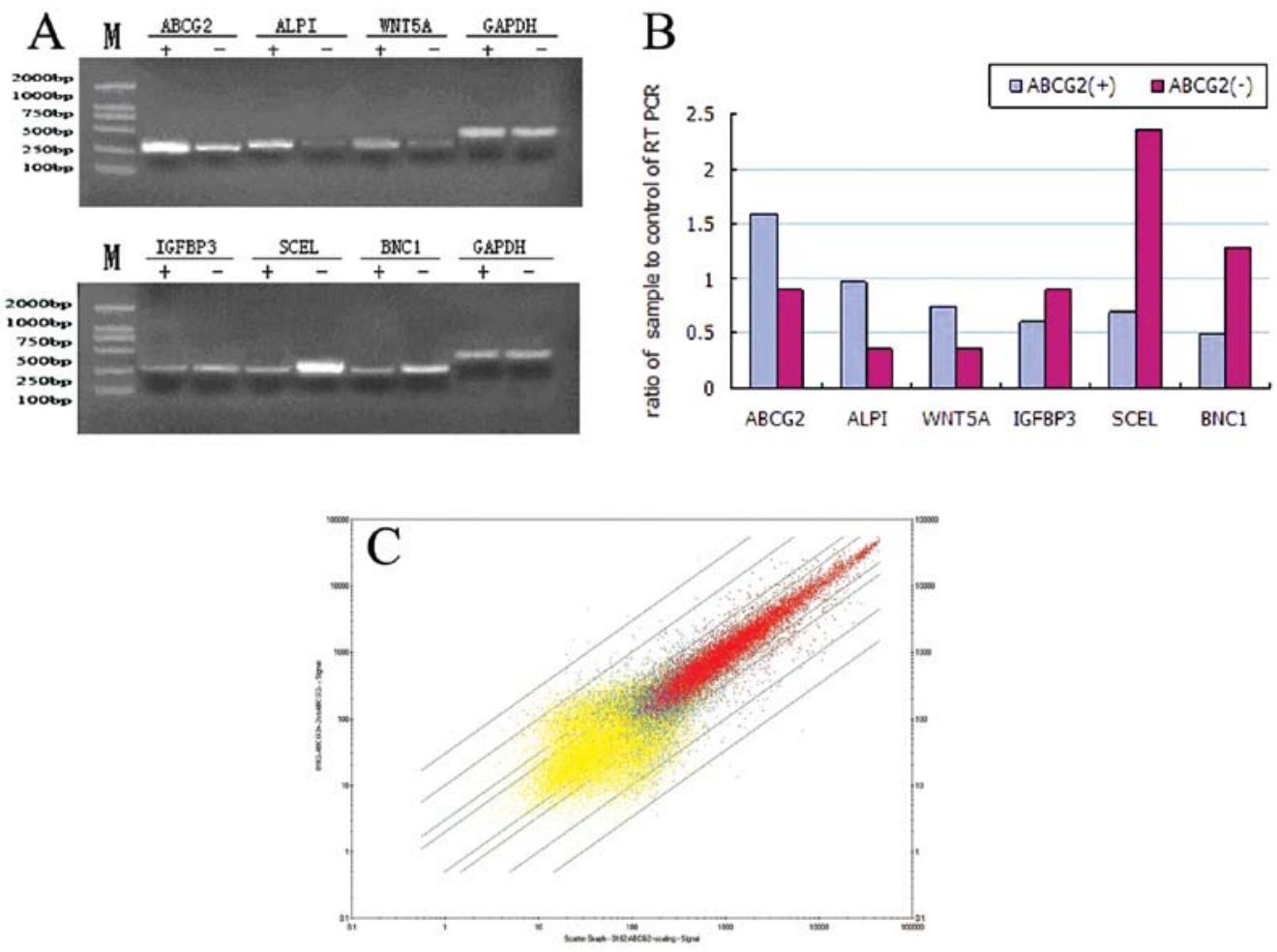

Figure 4. Gene expression profile of $\mathrm{ABCG}_{2}{ }^{+}$and $\mathrm{ABCG} 2$ cells. (A) Detection of differentially expressed genes by RT-PCR. ALPI, ABCG2 and WNT5A are highly expressed in $\mathrm{ABCG}^{+}$cells (upper figure), while IGFBP3, SCEL and BNC1 are highly expressed in ABCG2 cells (lower figure). GAPDH is used as internal control. (B) Expression levels of detected genes shown with bar chart. (C) The scatterplot of average expression value in $\mathrm{ABCG}^{+}$and $\mathrm{ABCG} 2^{-}$cells.

protein in charge of the efflux of chemotherapy drugs, metabolites and other compounds such as Hoechst 33342 dye, thus it is responsible for the phenotype of SP cells and has been widely used as a marker in CSCs isolated from retinoblastoma (45), embryonic (44), lung (41), liver (46), pancreas (47), gallbladder (48) and head and neck cancers (55) and NPC (23). Our results showed that there were approximately $62 \%$ of $\mathrm{ABCG} 2^{+}$cells in LRCs, suggesting that LRCs may represent a group of CSCs in NPC cells. This result is similar to that of research work of Welm et al (56). They found that the number of LRCs in SP cells was 4 times of those in non-SP cells.

Currently it is technically impossible to isolate LRCs from tumor tissue. We tried to sort $\mathrm{ABCG} 2^{+}$cells by MACS from 5-8F cells. The ABCG2-positive rate was $2.11 \%$, which is similar to those in other tumor cells (57). Subsequently, we identified the biological characteristics of these $\mathrm{ABCG}^{+}$ cells, and found that among $\mathrm{ABCG}^{+}, \mathrm{ABCG} 2^{-}$and unsorted $5-8 \mathrm{~F}$ cells, the rate of $\mathrm{ABCG} 2^{+}$cells were highest at $\mathrm{G} 0 / \mathrm{G} 1$ phase, while the rate of $\mathrm{ABCG} 2^{-}$cells were highest at $\mathrm{S}$ phase, indicating that $\mathrm{ABCG} 2^{+}$cells were mostly quiescent, and more ABCG2- cells were in DNA synthesis period. Therefore, some of the ABCG2- cells might be the transient amplifying cells that could proliferate rapidly. Among the three kinds of cells, the cloning efficiency of $\mathrm{ABCG} 2^{+}$cells was lower than that of ABCG2- cells and unsorted cells, and the tumorigenicity of $\mathrm{ABCG}^{+}$cells was also the lowest. We suppose that there may be several possibilities leading to the above results. One is that ABCG2 alone can not sufficiently enrich CSCs from 5-8F cells, therefore there are non-CSCs in $\mathrm{ABCG}^{+}$cells and there are some CSCs in ABCG2- cells. Another is that $\mathrm{ABCG}^{+}$cells are enriched in SP cells, but are not equal to SP cells, thus may not exhibit typical properties of CSCs. Our results are similar to those of Patrawala et al (57). They found that side population isolated from prostate cancer, breast cancer and glioma was enriched in tumorigenic, stem-like cancer cells, whereas $\mathrm{ABCG}^{+}$and $\mathrm{ABCG} 2^{-}$cancer cells were similarly tumorigenic.

To explore the molecular mechanism underlying the biological characteristics of $\mathrm{ABCG} 2^{+}$cells, Affymetrix oligonucleotide microarray was used to monitor expression of about 47,400 transcripts containing 38,500 known genes in $\mathrm{ABCG} 2^{+}$ and ABCG2 cells. There were 353 genes and ESTs upregulated significantly and 590 genes downregulated significantly in $\mathrm{ABCG}^{+}$cells. As analyzed by Gene Ontology, a group of genes generally involving in negative regulation of cell cycle were discovered in $\mathrm{ABCG}^{+}$but not in $\mathrm{ABCG}^{-}$cells. The stem cell associated genes PSCA, ABCG2 and ALPI were upregulated significantly in $\mathrm{ABCG}^{+}$cells, while $\mathrm{K} 19$, integrin $\alpha 6$, integrin $\beta 4, \mathrm{CD} 44$ and $\mathrm{K} 14$ were upregulated significantly in ABCG2- cells. Together with the fact that the rate of LRC in $\mathrm{ABCG}^{+}$cells is only $12 \%$, we suppose the most likely possibility is that ABCG2 alone is insufficient to mark CSCs in $5-8 \mathrm{~F}$ cells. Further study waits to be conducted to isolate and identify CSCs from NPC cells and NPC tissue.

\section{Acknowledgements}

This study was supported by National Basic Research Program of China (2010CB833605), Program for New Century Excellent Talents in University (NCET-10-0790), National Natural Science Foundation of China (30801322, 81172206) and Incubation Program for National Natural Science Funds for Distinguished Young Scholar. 


\section{References}

1. Thomson JA, Itskovitz-Eldor J, Shapiro SS, et al: Embryonic stem cell lines derived from human blastocysts. Science 282 $1145-1147,1998$

2. Shamblott MJ, Axelman J, Wang S, et al: Derivation of pluripotent stem cells from cultured human primordial germ cells. Proc Natl Acad Sci USA 95: 13726-13731,1998.

3. Pittenger MF, Mackay AM,Beck SC, et al: Multilineage potential of adult human mesenchymal stem cells. Science 284: 143-147, 1999.

4. Johansson CB, Momma S, Clarke DL, Risling M, Lendahl U and Frisen J: Identification of a neural stem cell in the adult mammalian central nervous system. Cell 96: 25-34, 1999.

5. Janes SM, Lowell S and Hutter C: Epidermal stem cells. J Pathol 197: 479-491, 2002

6. Brittan M and Wright NA: Gastrointestinal stem cells. J Pathol 197: 492-509, 2002.

7. Mason RJ, Williams MC, Moses HL, Mohla S and Berberich MA Stem cells in lung development, disease, and therapy. Am J Respir Cell Mol Biol 16: 355-363, 1997.

8. Schermer A, Galvin S and Sun TT: Differentiation-related expression of a major $64 \mathrm{~K}$ corneal keratin in vivo and in culture suggests limbal location of corneal epithelial stem cells. J Cell Biol 103: 49-62, 1986.

9. Goldring K, Partridge T and Watt D: Muscle stem cells. J Pathol 197: 457-467, 2002.

10. Strain AJ and Crosby HA: Hepatic stem cells. Gut 46: 743-745, 2000.

11. Bonner-Weir S and Sharma A: Pancreatic stem cells. J Pathol 197: 519-526, 2002

12. Fujino N, Kubo H, Suzuki T, et al: Isolation of alveolar epithelial type II progenitor cells from adult human lungs. Lab Invest 91: 363-378, 2011.

13. Reya T, Morrison SJ, Clarke MF and Weissman IL: Stem cells, cancer, and cancer stem cells. Nature 414: 105-111, 2001.

14. Pardal R, Clarke MF and Morrison SJ: Applying the principles of stem-cell biology to cancer. Nat Rev Cancer 3: 895-902, 2003.

15. Cox CV, Diamanti P, Evely RS, Kearns PR and Blair A Expression of CD133 on leukemia-initiating cells in childhood ALL. Blood 113: 3287-3296, 2009.

16. Charafe-Jauffret E, Ginestier C, Iovino F, et al: Breast cancer cell lines contain functional cancer stem cells with metastatic capacity and a distinct molecular signature. Cancer Res 69: 1302-1313, 2009.

17. Oates JE, Grey BR, Addla SK, et al: Hoechst 33342 side population identification is a conserved and unified mechanism in urological cancers. Stem Cells Dev 18: 1515-1522, 2009.

18. Huang EH, Hynes MJ, Zhang T, et al: Aldehyde dehydrogenase 1 is a marker for normal and malignant human colonic stem cells (SC) and tracks SC overpopulation during colon tumorigenesis. Cancer Res 69: 3382-3389, 2009.

19. Takaishi S, Okumura T, Tu S, et al: Identification of gastric cancer stem cells using the cell surface marker CD44. Stem Cells 27: 1006-1020, 2009.

20. Ma S, Chan KW, Lee TK, et al: Aldehyde dehydrogenase discriminates the CD133 liver cancer stem cell populations. Mol Cancer Res 6: 1146-1153, 2008.

21. Jiang T, Collins BJ, Jin N, et al: Achaete-scute complex homologue 1 regulates tumor-initiating capacity in human small cell lung cancer. Cancer Res 69: 845-854, 2009.

22. Roesch A, Fukunaga-Kalabis M, Schmidt EC, et al: A temporarily distinct subpopulation of slow-cycling melanoma cells is required for continuous tumor growth. Cell 141: 583-594, 2010.

23. Wang J, Guo LP, Chen LZ, Zeng YX and Lu SH: Identification of cancer stem cell-like side population cells in human nasopharyngeal carcinoma cell line. Cancer Res 67: 3716-3724, 2007.

24. Li C, Heidt DG, Dalerba P, et al: Identification of pancreatic cancer stem cells. Cancer Res 67: 1030-1037, 2007.

25. Li T, Su Y, Mei Y, et al: ALDH1A1 is a marker for malignant prostate stem cells and predictor of prostate cancer patients outcome. Lab Invest 90: 234-244, 2010.

26. Bussolati B, Bruno S, Grange C, Ferrando U and Camussi G: Identification of a tumor-initiating stem cell population in human renal carcinomas. FASEB J 22: 3696-3705, 2008.

27. Goodell MA, Brose K, Paradis G, Conner AS and Mulligan RC: Isolation and functional properties of murine hematopoietic stem cells that are replicating in vivo. J Exp Med 183: 1797-1806, 1996.
28. Alfakir M, Dawe N, Eyre R, et al: The temporal and spatial expression patterns of ABCG2 in the developing human heart. Int J Cardiol: Nov 24, 2010 (Epub ahead of print).

29. Watanabe K, Nishida K, Yamato M, et al: Human limbal epithelium contains side population cells expressing the ATP-binding cassette transporter ABCG2. FEBS Lett 565: 6-10, 2004.

30. Pascal LE, Oudes AJ, Petersen TW, et al: Molecular and cellular characterization of ABCG2 in the prostate. BMC Urol 7: 6, 2007.

31. Larderet G, Fortunel NO, Vaigot P, et al: Human side population keratinocytes exhibit long-term proliferative potential and a specific gene expression profile and can form a pluristratified epidermis. Stem Cells 24: 965-974, 2006.

32. Clarke RB, Spence K, Anderson E, Howell A, Okano H and Potten CS: A putative human breast stem cell population is enriched for steroid receptor-positive cells. Dev Biol 277: 443-456, 2005.

33. Challen GA, Bertoncello I, Deane JA, Ricardo SD and Little MH: Kidney side population reveals multilineage potential and renal functional capacity but also cellular heterogeneity. J Am Soc Nephrol 17: 1896-1912, 2006

34. Salcido CD, Larochelle A, Taylor BJ, Dunbar CE and Varticovski L: Molecular characterisation of side population cells with cancer stem cell-like characteristics in small-cell lung cancer. Br J Cancer 102: 1636-1644, 2010.

35. Yin B, Yang Y, Zhao Z, et al: Arachidonate 12-lipoxygenase may serve as a potential marker and therapeutic target for prostate cancer stem cells. Int J Oncol 38: 1041-1046, 2011.

36. Tabuse M, Ohta S, Ohashi Y, et al: Functional analysis of HOXD in human gliomas and glioma cancer stem cells. Mol Cancer 10: $60,2011$.

37. Feuring-Buske M and Hogge DE: Hoechst 33342 efflux identifies a subpopulation of cytogenetically normal CD34(+)CD38(-) progenitor cells from patients with acute myeloid leukemia. Blood 97: 3882-3889, 2001.

38. Hirschmann-Jax C, Foster AE, Wulf GG, et al: A distinct 'side population' of cells with high drug efflux capacity in human tumor cells. Proc Natl Acad Sci USA 101: 14228-14233, 2004.

39. Haraguchi $\mathrm{N}$, Utsunomiya $\mathrm{T}$, Inoue $\mathrm{H}$, et al: Characterization of a side population of cancer cells from human gastrointestinal system. Stem Cells 24: 506-513, 2006.

40. Mitsutake N, Iwao A, Nagai K, et al: Characterization of side population in thyroid cancer cell lines: cancer stem-like cells are enriched partly but not exclusively. Endocrinology 148: 1797-1803, 2007.

41. Ho MM, Ng AV, Lam S and Hung JY: Side population in human lung cancer cell lines and tumors is enriched with stem-like cancer cells. Cancer Res 67: 4827-4833, 2007.

42. Schinkel AH and Jonker JW: Mammalian drug efflux transporters of the ATP binding cassette (ABC) family: an overview. Adv Drug Deliv Rev 55: 3-29, 2003.

43. Doyle LA, Yang W, Abruzzo LV, et al: A multidrug resistance transporter from human MCF-7 breast cancer cells. Proc Natl Acad Sci USA 95: 15665-15670, 1998.

44. Inowa T, Hishikawa K, Matsuzaki Y, et al: GADD45 $\beta$ determines chemoresistance and invasive growth of side population cells of human embryonic carcinoma. Stem Cells Int 2010: 782967, 2010.

45. Ma B, Lei X, Guan Y, et al: Maintenance of retinal cancer stem cell-like properties through long-term serum-free culture from human retinoblastoma. Oncol Rep 26: 135-143, 2011.

46. Shi GM, Xu Y, Fan J, et al: Identification of side population cells in human hepatocellular carcinoma cell lines with stepwise metastatic potentials. J Cancer Res Clin Oncol 134: 1155-1163, 2008.

47. Wang YH, Li F, Luo B, et al: A side population of cells from a human pancreatic carcinoma cell line harbors cancer stem cell characteristics. Neoplasma 56: 371-378, 2009.

48. Yin BB, Wu SJ, Zong HJ, Ma BJ and Cai D: Preliminary screening and identification of stem cell-like sphere clones in a gallbladder cancer cell line GBC-SD. J Zhejiang Univ Sci B 12: 256-263, 2011

49. Zhang HB, Ren CP, Yang XY, et al: Identification of labelretaining cells in nasopharyngeal epithelia and nasopharyngeal carcinoma tissues. Histochem Cell Biol 127: 347-354, 2007.

50. Zhang H, Feng X, Liu W, et al: Underlying mechanisms for LTF inactivation and its functional analysis in nasopharyngeal carcinoma cell lines. J Cell Biochem 112: 1832-1843, 2011

51. Zhao M, Ren C, Yang H, et al: Transcriptional profiling of human embryonic stem cells and embryoid bodies identifies HESRG, a novel stem cell gene. Biochem Biophys Res Commun 362: 916-922, 2007 
52. Cotsarelis G, Sun TT and Lavker RM: Label-retaining cells reside in the bulge area of pilosebaceous unit: implications for follicular stem cells, hair cycle, and skin carcinogenesis. Cell 61: $1329-1337,1990$.

53. Potten CS: Keratinocyte stem cells, label-retaining cells and possible genome protection mechanisms. J Investig Dermatol Symp Proc 9: 183-195, 2004.

54. Cairns J: Mutation selection and the natural history of cancer. Nature 255: 197-200, 1975.

55. Tabor MH, Clay MR, Owen JH, et al: Head and neck cancer stem cells: the side population. Laryngoscope 121: 527-533, 2011.
56. Welm BE, Tepera SB, Venezia T, Graubert TA, Rosen JM and Goodell MA: Sca-1(pos) cells in the mouse mammary gland represent an enriched progenitor cell population. Dev Biol 245: 42-56, 2002.

57. Patrawala L, Calhoun T, Schneider-Broussard R, Zhou J, Claypool K and Tang DG: Side population is enriched in tumorigenic, stem-like cancer cells, whereas $\mathrm{ABCG} 2^{+}$and ABCG2- cancer cells are similarly tumorigenic. Cancer Res 65 : 6207-6219, 2005 